\title{
ROAD SAFETY EDUCATION FOR CHILDREN: RESULTS OF CHILDREN'S BEHAVIOR ON TRAFFIC PLAYGROUND AND SIMULATED TRAFFIC SITUATIONS
}

UDC 656.1 : 37.018; 656.1 .05 (02.053.2)

\section{Dalibor Pešić, Aleksandar Trifunović, Maja Petrović}

The Faculty of Transport and Traffic Engineering, University of Belgrade, Serbia

\begin{abstract}
Child pedestrians are highly represented in fatal and severe road crashes and differ in their crossing behavior from adults. Child pedestrians are disproportionately vulnerable to road traffic injuries, but it is unclear which aspects of pedestrian safety behaviors develop at what age. To create effective intervention programs, research on which pedestrian safety risks occur among which age group and urban/rural areas, is needed. For these reasons, an experiment was conducted to examine the behavior of children on traffic playground and simulated traffic situations (STS). The key results this study showed children have a higher percentage of accurate responses to the STS environment, than on traffic playground. Thereby, it is important to take those findings in account when aiming to train children for road safety. The experiment represents a basis for the creation of individualized educational interventions to help children adapt to the basic traffic safety behavior rules.
\end{abstract}

Key words: traffic safety, education, learning, school children, behavior.

\section{INTRODUCTION}

According to World Health Organization (WHO) estimates, 186,300 children die annually from road traffic crashes globally, equal to over 500 child deaths daily. Road traffic injury ranks among the top four global causes of death in children between the ages of 5 and 14 years. Among these deaths, 38\% of the children are pedestrians (Schwebel, Davis \& O’Neal, 2012; World Health Organization, 2015).

Active play, particularly when performed outdoors, is a spontaneous, self-motivated, fun, and unstructured form of physical activity that provides children with physical,

Received February 07, 2019/Accepted June 20, 2019

Corresponding author: Aleksandar Trifunović

The Faculty of Transport and Traffic Engineering, University of Belgrade, Vojvode Stepe 305, 11000 Beograd, Serbia Phone: +381 11309 1245•E-mail: a.trifunovic@sf.bg.ac.rs 
mental, and social health benefits (Tremblay, Gray, Babcock, et al., 2015) and (Burdette $\&$ Whitaker, 2005). Pedestrian spaces could be explored through mental or cognitive maps (Vukmirović \& Folić, 2017), or by examining the behavior of pedestrians. One potential correlate of outdoor active play is the extent to which children are safe and protected from motorized vehicle traffic while playing outdoors or travelling to outdoor play destinations (Nguyen, Borghese, \& Janssen, 2018). Child pedestrians are disproportionately vulnerable to road traffic injuries, but it is unclear which aspects of pedestrian safety behaviors develop at what age (Wang, Tan, Schwebel, Shi, \& Miao, 2018).

Children constitute an important share of the road users, and even if they are not allowed to drive motorized vehicles (only bicycle) themselves and therefore seldom hurt other road users, their ability to anticipate hazards can protect them from being hit by others, such as when crossing the road (Meyer, Sagberg, \& Torquato, 2014). Their ability to perceive unsafe situations can also reduce the likelihood that they will end up in accidents. Previous studies have aimed at identifying factors of child pedestrian risk. For instance, in relation to the most common road traffic accident situation among children, unsafe street crossing, studies show that advanced perceptual and cognitive skills are needed (Schacter \& Jo, 2016). Research shows that young children have lower hazard perception skills than adults (Meyer, Sagberg, \& Torquato, 2014) and are more prone to impulsive actions in traffic (Briem \& Bengtsson, 2000). Children have difficulty assessing a car's approaching speed and therefore interpret distance between themselves and a car as greater than it actually is (Connelly, Conalen, Parsonson, \& Isler, 1998). Further, even if children may choose the same gap size for crossing the street, their risk of accident involvement is increased as they delay the start of the crossing, thereby reducing the available time to cross the street safely (Pitcairn \& Edlmann, 2000).

In order to understand the complexity of the pedagogical process and children's behaviors it is necessary to study all those important contextual elements that influence the formation of certain conditions which govern the educational work with school children, and to study all the qualitative components which are the essence of the pedagogical process (Tanić, Stanković, Nikolić, \& Kostić, 2016; Stošić \& Mitić 2018), as well as examine the knowledge and behavior of children. For these reasons, an experiment was conducted to examine the behavior of children on traffic playground and simulated traffic situations (STS), which shows another aspect of applying modeling in traffic (Filipova, Stojadinova, \& Hadjiatanasova, 2002).

\section{MethodOLOGY}

\subsection{Participants and Experiment Procedure}

In the experiment 48 respondents participated. Of the total number of respondents, 29 were females and 29 males. The facilities of educational institutions from rural or urban environments providing state-funded preschool and school education programs was chosen as a venue for experiment realization (29 respondents from urban and 29 from urban area). The sample is comprised of several groups: children attending primary school, from the first (aged from 6.5 to 7.5 years), second (aged from 7.5 to 8.5 years), third grade (ages from 8.5 to 9.5 years) and fourth grade (ages from 9.5 to 10.5 years). For children that grow up today, digital media are part of everyday life, and they accept 
technology as a completely natural and inevitable means. The old notion that children must reach the level of specific operations to get ready to use a computer is outdated. Children find tablet PCs highly motivating, and learn how to use them almost immediately (Flewitt, Messer, \& Kucirkova, 2015; Schacter \& Jo, 2016). Tablets are lightweight and mobile, permitting children to play and learning with them indoors and out-doors (Trifunović, Čičević, Dragović, \& Petrović, 2018). These properties make those devices particularly suitable for education in natural environment. For this reason, used the simulated traffic situation on Tablet PC (Agencija za bezbednost saobraćaja Republike Srbije, 2018). Traffic playground is created and made by the author this paper. Identical traffic situations are presented on Tablet PC and in simulated traffic environment. All subjects were tested for two different conditions and all traffic situations (Table 1).

Table 1 Traffic situations presented to children

\begin{tabular}{|c|c|c|}
\hline Traffic situations & Traffic Playground & STS \\
\hline $\begin{array}{l}\text { Behavior at the traffic light for } \\
\text { pedestrians (red and green light); }\end{array}$ & & \\
\hline
\end{tabular}

Behavior at the traffic light for cyclists (red and green light);

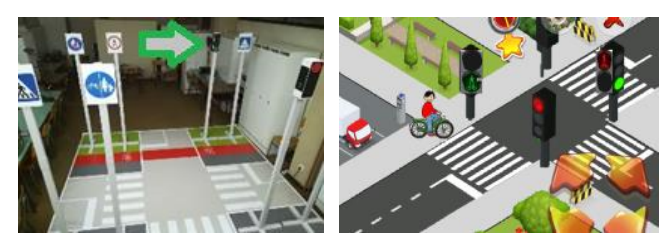

Crossing the street on a pedestrian crossing;

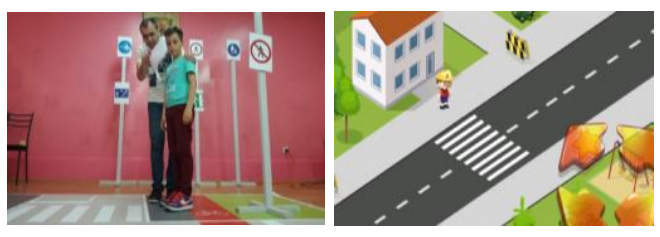

Crossing the street outside a pedestrian crossing.
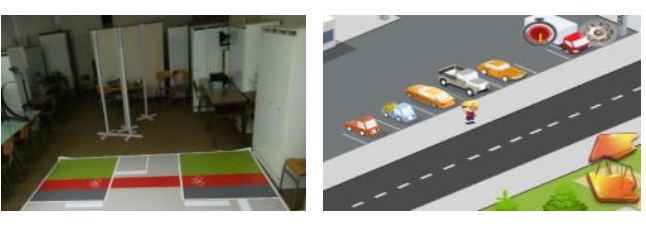


\subsection{Participants and Experiment Procedure}

The answers were recorded in paper form. These data are loaded and processed in a database made in MS Excel. Statistical analysis was performed by the statistical software package IBM SPSS Statistics v. 22. Based on the results of descriptive statistics and cross tabulation it was presented the basic statistical analysis of data obtained in the experiment. Normality distribution was tested by inspection of histograms and the Kolmogorov-Smirnov test. As the Kolmogorov-Smirnov test has determined that results do not significantly deviate from a normal distribution, the decision was to use Student's T-test and ANOVA. Dunnett's T3 Post Hoc test has been used for additional comparison (Trifunović, Čičević, Lazarević, Nešić, \& Dragović, 2018) and (Trifunović, Čičević, Lazarević, Nešić, \& Dragović, 2018). All tests were carried out based on the recommendations of the textbook "SPSS Survival Manual" (Pallant, 2013). The threshold of statistical significance $(\alpha)$ is set at $5 \%$.

\section{RESULTS AND DISCUSSION}

In this experiment, all respondents were able to recognize the traffic concepts of sidewalk, roadway, bicycle path, pedestrian and bicycle traffic light, on the traffic playground and STS. The rest of this paper will present the results of the behavior of children on traffic playground and geometrically modeled traffic situations in different traffic situations.

Figures 1 and 2 shows descriptive statistics of the correct responses of children for behavior in traffic situations (on the traffic playground and STS). Children have 100\% correct responses when a red light is on the pedestrian and bicycle traffic lights, on the traffic playground and STS. For all other traffic situations, children have a higher percentage of accurate responses to the STS environment.

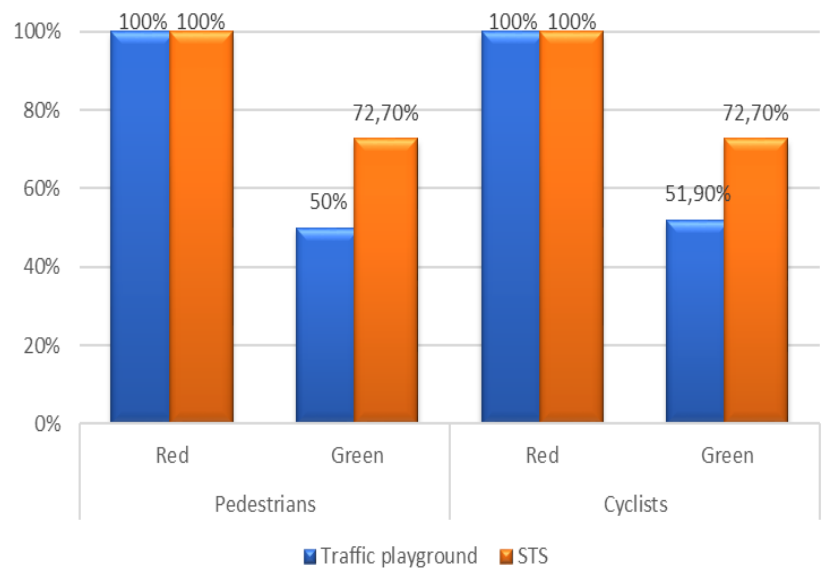

Fig. 1 Percentage of accurate responses of children for traffic light for pedestrians and cyclists 
Road Safety Education for Children: Results of Children's Behavior on Traffic Playground and Simulated... 5

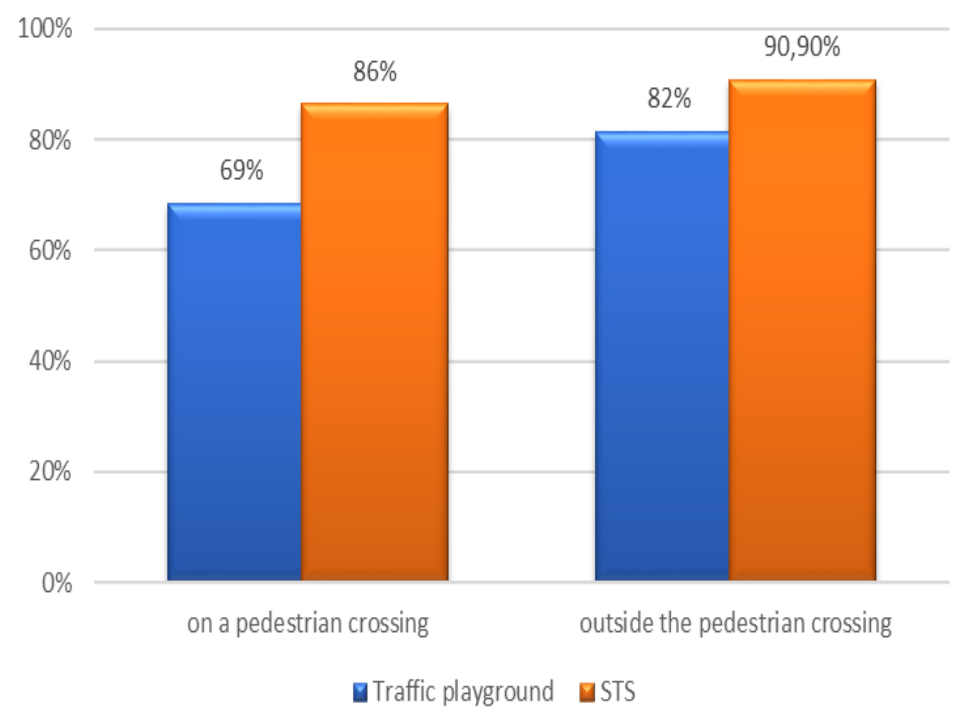

Fig. 2 Percentage of accurate responses of children for crossing the street

\subsection{Participants and Experiment Procedure}

The results of One-way ANOVA showed statistically significant differences in interpreting the green light for pedestrians on a traffic signal among the children in different grades children $(\mathrm{F}=3.454 ; \mathrm{p}=0.006)$ for traffic playground, and $(\mathrm{F}=2.842 ; \mathrm{p}=0.008)$ for STS.

There are also statistically significant differences for green traffic lights for cyclists with respect to participants age $(\mathrm{F}=2.947 ; \mathrm{p}<0.009)$ for traffic playground, and $(\mathrm{F}=2.645 ; \mathrm{p}=$ $0.010)$ for STS.

The results showed statistically significant differences for crossing the street on a pedestrian crossing $(\mathrm{F}=4.121 ; \mathrm{p}<0.003)$ for traffic playground, and $(\mathrm{F}=4.455 ; \mathrm{p}=0.003)$ for STS. Also, the results showed statistically significant differences for crossing the street outside of pedestrian crossing $(\mathrm{F}=4.121 ; \mathrm{p}<0.003)$ for traffic playground, and $(\mathrm{F}=4.455 ; \mathrm{p}$ $=0.003$ ) for STS. Based on the data shown above we can conclude that older children show better knowledge and understanding of traffic rules in different traffic situations, for both conditions. In other words, there are significant differences in children answers, i.e., the knowledge upon traffic situations for the first in comparison to the third and fourth grade, as well for the second in comparison to the third and fourth grade.

Figures shows descriptive statistics on children's accuracy, by age group and traffic playground/STS environment, for behavior in different traffic situations (Figure 3 - traffic light for pedestrians; Figure 4 - traffic light for cyclists; Figure 5 - for crossing the street). 


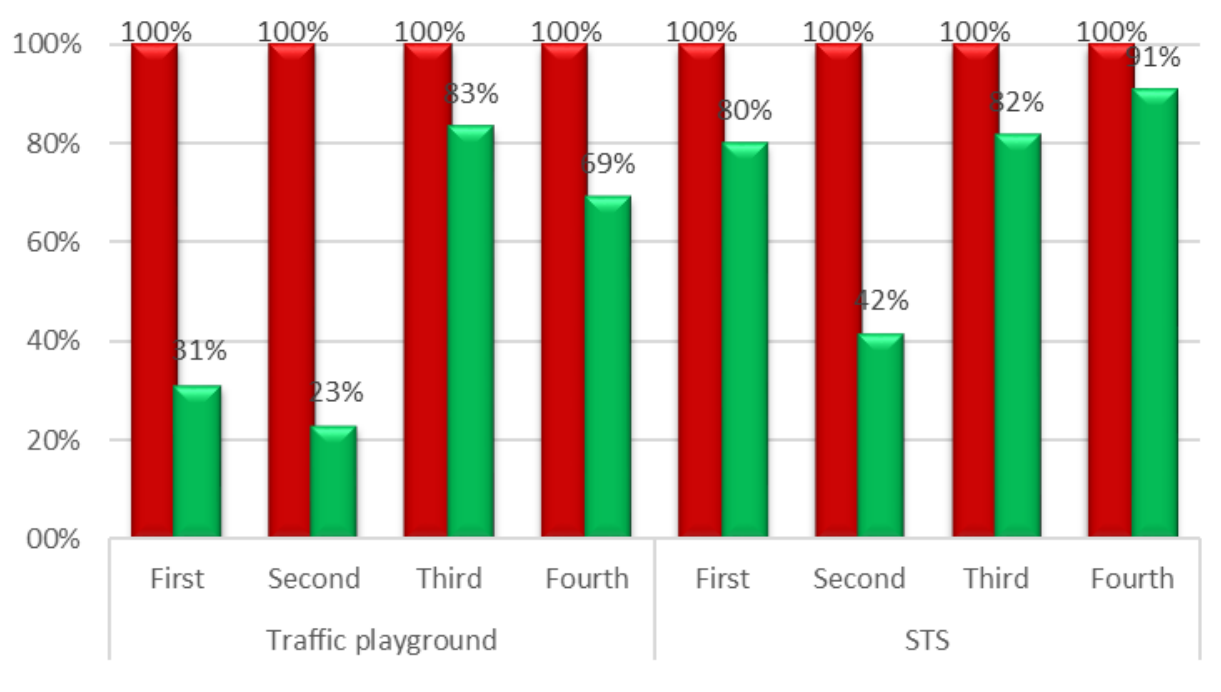

a $\mathbf{B}$ Green

Fig. 3 Percentage of accurate responses of children for traffic light for pedestrians - Age differences

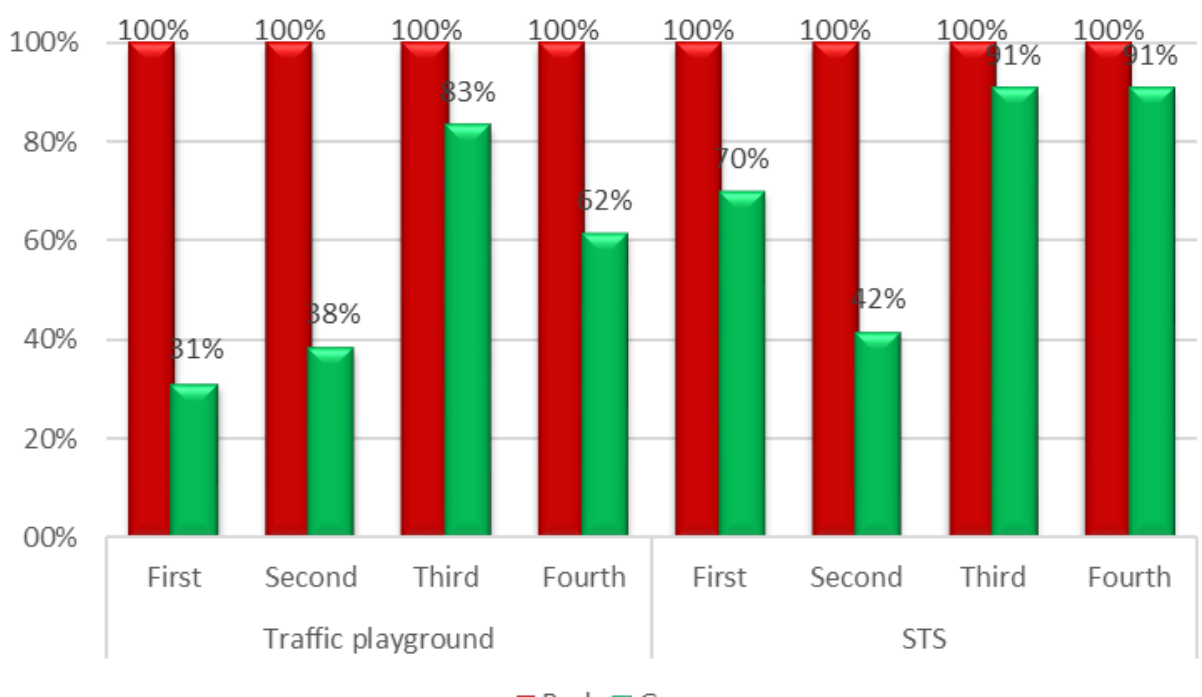

घhed $\mathbf{q}$ Green

Fig. 4 Percentage of accurate responses of children for traffic light for cyclists - Age differences 


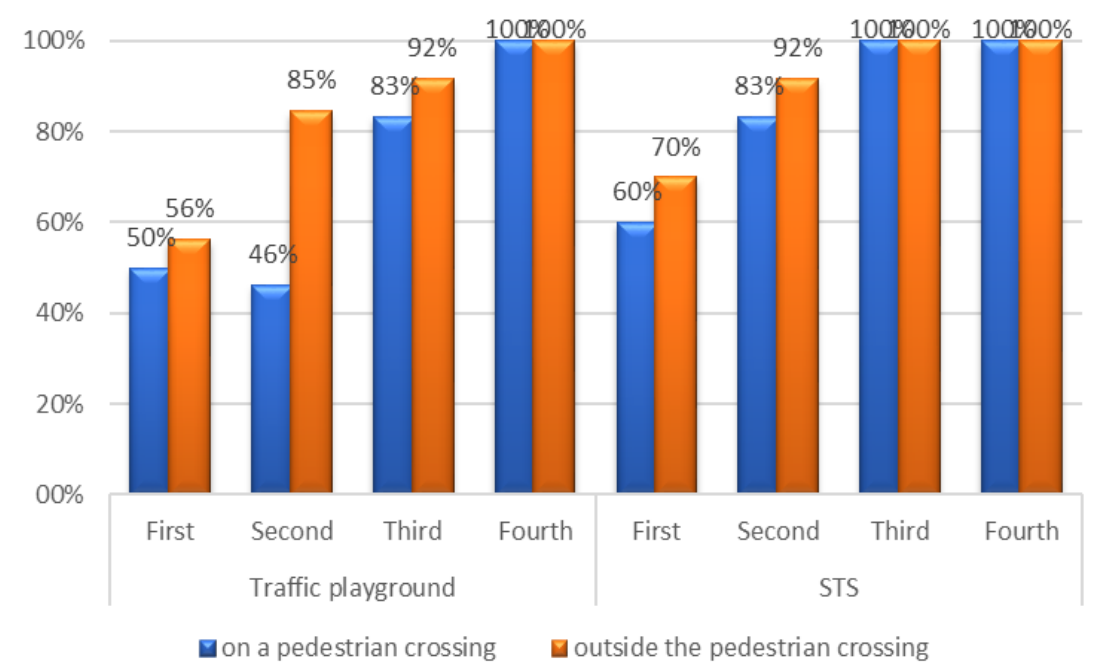

Fig. 5 Percentage of accurate responses of children for crossing the street - Age differences

\subsection{Urban and Rural Areas}

Figures 6 and 7 shows the percentage of correct answers of children for behavior in traffic situations (pedestrian and bicycle traffic lights, respectively), from the urban and rural environment. The results of Student's T-Test showed statistically significant areas (urban and rural) differences for: cross the street on a pedestrian crossing $(\mathrm{t}=-1.075 ; \mathrm{p}=0.032)$ and cross the street outside a pedestrian crossing $(\mathrm{t}=-2.895 ; \mathrm{p}<0.001)$, for traffic playground and STS. There are not statistically significant areas differences for other behavior in traffic. Children from the urban area have a higher percentage of correct answers of the traffic playground, while children from rural area have a higher percentage of correct answers of the STS. Figure 7 show descriptive statistics on children's accuracy, for crossing the street.

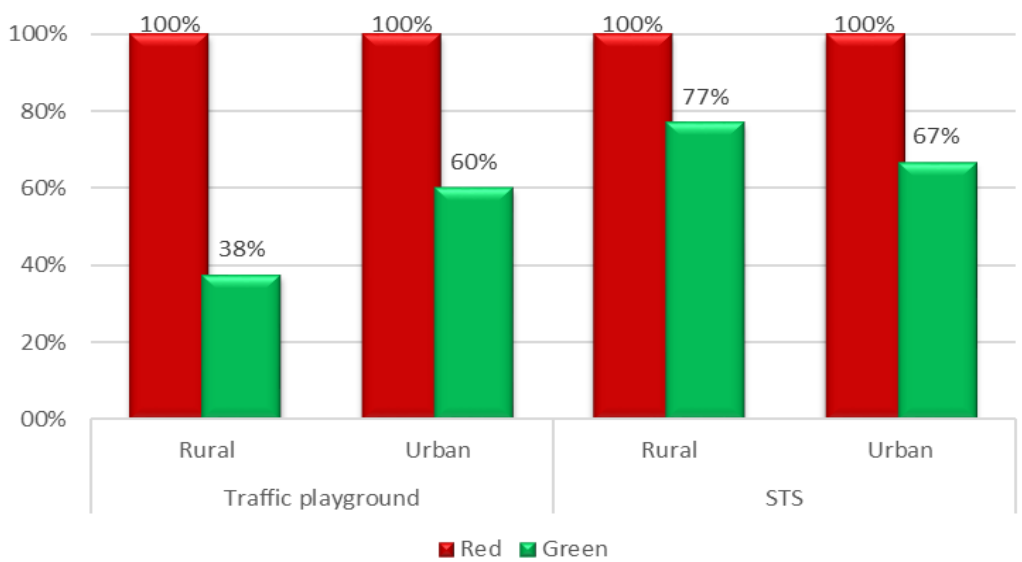

Fig. 6 Percentage of accurate responses of children for traffic light for pedestrians Urban and Rural Areas 


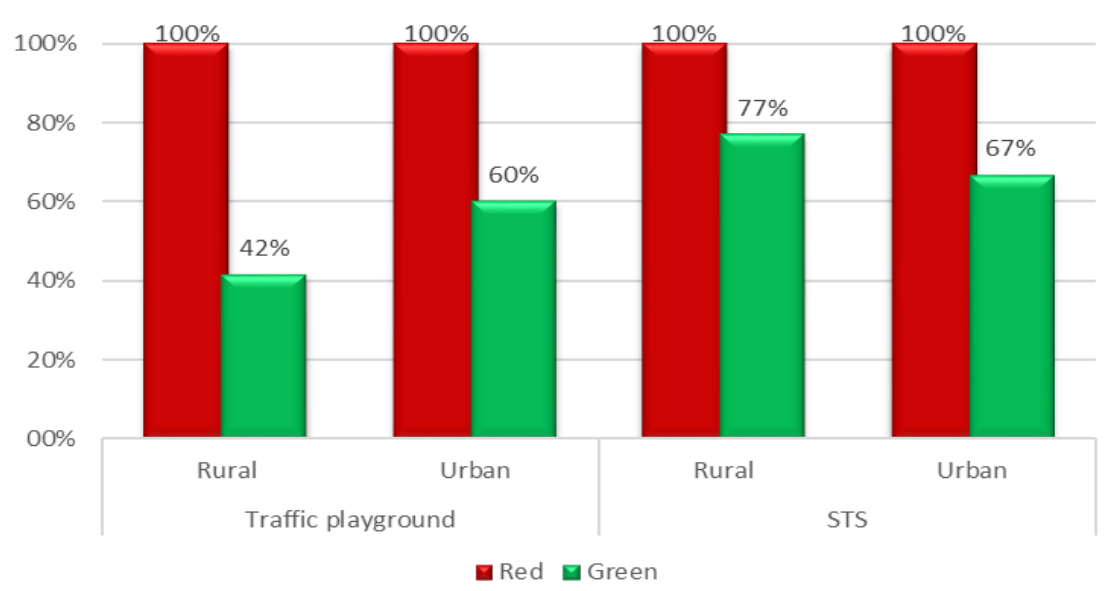

Fig. 7 Percentage of accurate responses of children for traffic light for cyclists - Urban and Rural Areas

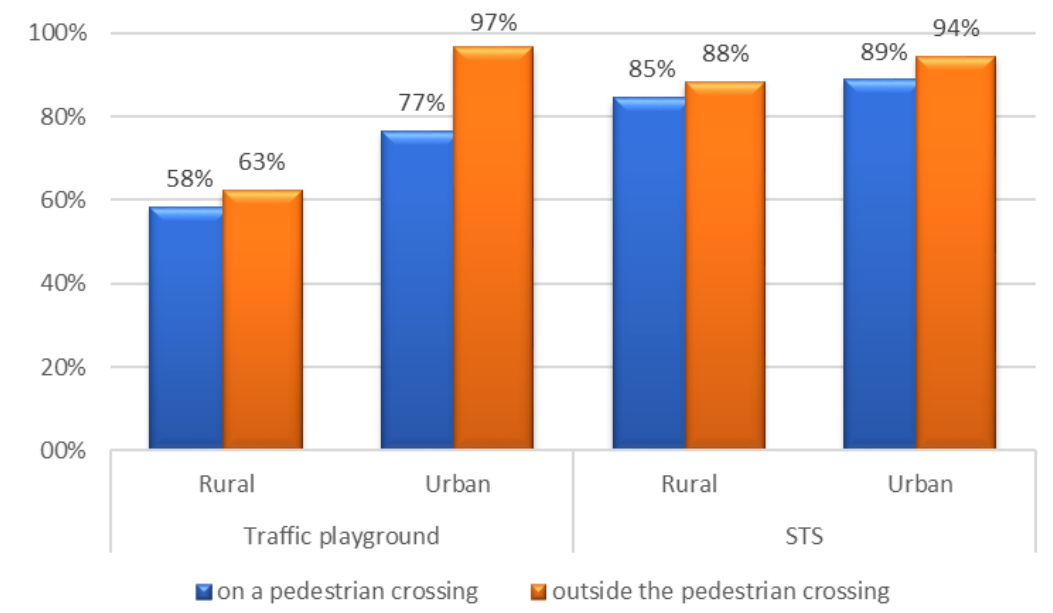

Fig. 8 Percentage of accurate responses of children for crossing the street - Urban and Rural Areas

\section{CONCLUSIONS}

Based on the data collected and analyzed in our research, it can be derived general conclusions:

- Children have a higher percentage of accurate responses to the GMTS environment;

- Older children have a higher percentage of correct answers on the traffic playground and GMTS;

- Children from the urban area have a higher percentage of correct answers of the traffic playground;

- Children from rural area have a higher percentage of correct answers of the GMTS. 
In conclusion, child pedestrian behavior on traffic playground brings higher risks into traffic safety, than on GMTS, most probably due to immaturity and lack of experience in real traffic situations. A better understanding of how children respond to the different experimental environment (traffic playground and GMTS) can be used for the improvements of traffic safety children education. The experiment represents a basis for the creation of individualized educational interventions to help children adapt to the basic traffic safety behavior rules. Future research could include the difference between the new different traffic situations, as well as different age group respondents. Selection of the appropriate level-of-detail of the simulation traffic situations for the application at hand is another interesting topic for further research, special for different age groups of respondents. This is not commonly discussed in the traffic simulation literature. This is consequently an important topic for further research.

Acknowledgement. This study was supported by The Ministry of Education, Science and Technological Development of Serbia (project 36027 and 36022).

\section{REFERENCES}

Briem, V., \& Bengtsson, H. (2000). Cognition and Character Traits as Determinants of Young Children's Behaviour in Traf Situations. Int. J. Behav. Dev. 24(4), 492-505.

Burdette, H. L., \& Whitaker, R. C. (2005). Resurrecting Free Play in Young Children: Looking Beyond Ftness and Fatness to Attention, Affiliation, and Affect. Arch. Pediatr. Adolesc. Med. 159(1), 46-50.

Connelly, M. L., Conalen, H. M., Parsonson, B. S., \& Isler, R. B. (1998). Child Pedestrians' Crossing Gap Tresholds. Accid. Anal. Prev. 30(4), 443-453.

Filipova, K., Stojadinova, T., \& Hadjiatanasova, V. (2002). Application of Petri Nets for Transport Streams Modeling. Facta Universitatis, Series: Architecture and Civil Engineering, 2(4), 295-306.

Flewitt, R., Messer, D., \& Kucirkova, N. (2015). New Directions for Early Literacy in a Digital Age: The iPad. Journal of Early Childhood Literacy, 15(3), 289-310.

Meyer, S., Sagberg, F., \& Torquato, R. (2014). Traffic Hazard Perception Among Children. Transportation research part F: traffic psychology and behaviour, 26, 190-198.

Nguyen, A., Borghese, M. M., \& Janssen, I. (2018). Pedestrian Traffic Safety and Outdoor Active Play Among 1013 Year Olds Living in a Mid-sized City. Preventive medicine reports, 10, 304-309.

Pallant, J. (2013). SPSS survival manual. McGraw-Hill Education (UK).

Pažljivko Android app. Agencija za bezbednost saobraćaja Republike Srbije. https://play.google.com/store/apps/ details?id=com.rs.gov.abs.com.rs.gov.abs.pazljivko, at date 11.10.2018.

Pitcairn, T. K., Edlmann, T. (2000). Individual Differences in Road Crossing Ability in Young Children and Adults. Br. J. Psychol. 91, 391-410.

Schacter, J., \& Jo, B. (2016). Improving Low-income Preschoolers Mathematics Achievement with Math Shelf, a Preschool Tablet Computer Curriculum. Computers in Human Behavior, 55, 223-229.

Schwebel, D. C., Davis, A. L., \& O’Neal, E. E. (2012). Child Pedestrian Injury: A Review of Behavioral Risks and Preventive Strategies. Am. J. Lifestyle Med. 292-302.

Tanić, M., Stanković, D., Nikolić, V., \& Kostić, A. (2016). The Impact of Pedagogical Concepts of Social Environment on the Organization of the Physical Environment. Facta Universitatis, Series: Architecture and Civil Engineering, 14(2), 257-264.

Tremblay, M. S., Gray, C., Babcock, S., et al., (2015). Position Statement on Active Outdoor Play. Int. J. Environ. Res. Public Health 12(6), 6475-6505.; Suppl, S99-123 (e12).

Trifunović, A., Čičević, S., Dragović, M., \& Petrović, M. (2018). Differences in the Behavior of Children in Traffic Situations Presented on Mobile Devices and on the Polygon. 13 th International Conference "Road Safety in Local Community”, Serbia, Kopaonik, 305-314

Stošić, A. S., \& Mitić, I. T. (2018). Application of Integrative Teaching in Primary School Teaching Practice. Facta Universitatis, Series: Teaching, Learning and Teacher Education, 1(1), 113-123. 
Trifunović, A., Čičević, S., Lazarević, D., Nešić, M., \& Dragović, M. (2018). Comparing Tablets (Touchscreen devices) and PCs in Preschool Children' Education: Testing spatial relationships using geometric symbols on traffic signs. IETI Transactions on Ergonomics and Safety, Hong Kong, China, 2(1), 35-41.

Trifunović, A., Pešić, D., Čičević, S., \& Antić, B. (2017). The Importance of Spatial Orientation and Knowledge of Traffic Signs for Children's Traffic Safety. Accident Analysis \& Prevention, 102, 81-92.

Vukmirović, M., \& Folić, B. (2017). Cognitive Performances of Pedestrian Spaces. Facta Universitatis, Series: Architecture and Civil Engineering, 15(1), 43-57.

Wang, H., Tan, D., Schwebel, D. C., Shi, L., \& Miao, L. (2018). Effect of Age on Children's Pedestrian Behaviour: Results from an Observational Study. Transportation Research Part F: Traffic Psychology and Behaviour, 58, 556-565.

World Health Organization. (2015). Global status report on road safety 2015. World Health Organization.

\section{EDUKACIJA DECE O BEZBEDNOSTI U SAOBRAĆAJU: REZULTATI PONAŠANJA DECE NA SAOBRAĆAJNOM POLIGONU I U SIMULIRANIM SAOBRAĆAJNIM SITUACIJAMA}

Deca koja u saobraćaju učestvuju kao pešaci čine veliki procenat povređenih i poginulih lica u saobraćajnim nezgodama. Ponašanje u saobraćajnim situacijama znatno se razlikuje kod dece $i$ odraslih osoba. Deca pešaci imaju veliki rizik učestvovanja u saobraćajnim nezgodama, najčešće zbog nezrelosti psihofizičkih karakteristika, koje se vremenom kod dece menjaju. U cilju stvaranja bezbednog sistema dece u saobraćaju, potrebno je istražiti rizike koji dovode do stradanja dece pešaka u saobraćaju, a posebno treba analizirati razlike između dece iz urbanih i urbanih područja, kao $i$ različite starosne grupe dece. Navedeni razlozi su inicirali sprovođenje eksperimentalnog istraživanja koje ima cilj da ispita ponašanje dece na saobraćajnom poligonu $i$ u simuliranim saobraćajnim situacijama. Ključni rezultati prikazani u ovom radu pokazali su da deca imaju veći procenat tačnih odgovora, odnosno bezbednije se ponašaju u simuliranim saobraćajnim situacijama, nego $u$ identičnim situacijama koje se simuliraju na saobraćajnom poligonu. Navedeni rezultati predstavljaju važnu osnovu $i$ bitan aspekt unapređenja edukacije dece u oblasti bezbednosti saobraćaja. Eksperiment predstavlja osnovu za kreiranje individualizovanih edukativnih intervencija koje će pomoći deci da se prilagode osnovnim pravilima ponašanja u saobraćaju.

Ključne reči: bezbednost saobraćaja, edukacija, učenje, deca osnovno-školskog uzrasta, ponašanje. 